Journal of Engineering and Applied Sciences 14 (12): 4018-4021, 2019

ISSN: 1816-949X

(C) Medwell Journals, 2019

\title{
Grinding Smashed Granite for Water Filtration Purposes
}

\author{
Layla Abdulkareem Mokif \\ Environmental Research and Studies Center, University of Babylon, Babylon, Iraq
}

\begin{abstract}
In this study, the possibility of using wastes of construction, especially, the waste of granite in water filtration is considered. A pilot plant is designed consisting of two columns, the first one is a sand filter which is used for comparison while the second one is the assigned granite filter. The pilot plant was run for two times, the first run was carried out with filtration rate of $5 \mathrm{~m} / \mathrm{h}, \mathrm{pH}$ of 7.6 , Total Dissolved Solids (TDS) of $595 \mathrm{ppm}$, Temperature (T) of $30^{\circ} \mathrm{C}$ and Electrical conductivity (Ec) of $1193 \mu \mathrm{S} / \mathrm{cm}$ while the second run was carried out with filtration rate of $7.5 \mathrm{~m} / \mathrm{h}, \mathrm{pH}$ of 7.8 , TDS of $621 \mathrm{ppm}, \mathrm{Ec}$ of $1237 \mu \mathrm{sec} / \mathrm{cm}$ and T of $31^{\circ} \mathrm{C}$. The maximum values of turbidity removal efficiency corresponding to first run for sand and granite filters are 84.89 and 84.12 , respectively while the maximum values of turbidity removal efficiency corresponding to second run for sand and granite filters are 80.66 and 74.77 , respectively. The results show that the maximum values of removal efficiency of Total Suspended Solid (TSS) corresponding to first run are 84.77 and 82.44 for sand and granite filters, respectively while the maximum values corresponding to second run are 80.55 and 76.68 for sand and granite filters, respectively. The results corresponding to both runs demonstrate that the removal efficiency of turbidity and TSS of granite filter approach the removal efficiency of sand filter, thus, it can be deduced that the granite filter yields satisfactory results as a filter media.
\end{abstract}

Key words: Water treatment, filtration, turbidity removal, filter media, total suspended solid, electrical conductivity

\section{INTRODUCTION}

Filtration is an important stage of the water treatment processes used in the production of potable water, including the passage of water through porous material. The filtration process can improve both physical and microbiological quality. The essential purpose of the filtration process is to remove the water turbidity that is mainly composed of suspended particles (silt and clay), biological particles (plankton, bacteria) and floc. Filtration can also remove dissolved components such as phosphorus and metal ions. This step significantly enhances water quality by removing most suspended particles and bacteria found in the water, making them almost drinkable (Binnie et al., 2002). Furthermore, water filters differ in design and operational characteristics because of the technology and materials used which vary from place to place, resulting in considerable difference in their performance upon specific water pollutants (Kiagho et al., 2016). Direct filtration is considered as an appropriate process for treating surface water with low turbidity. The replacement of the conventional treatment system by direct filtration can significantly increase cost savings (up to $35 \%$ ), due to the elimination of traditional sedimentation (Zouboulis et al., 2007). The properties of filter media have great impacts in influencing filter performance in addition to selecting the media. The characteristics comprising size, shape, density, hardness and the granular bed created by grain are also important. Although, the choice of the type of the filter media and characteristics are representing the main core of any filtration process, the selection of the required system is usually dependent on arbitrary decisions, traditions or standard approaches (Gholikandi et al., 2012). The filter media is usually contained in the concrete filter tanks, all of the same size but the size will vary greatly from work to work. In general, the minimum number of filters is to allow one filter to be out of service, yet sufficient capacity is available to meet the average demand (Bourke et al., 1995). One of the most popular materials is the sand and its traditional exploitation in water treatment plants due to its widespread availability, acceptable low cost and the convincing results of its use as a filtration material. Sand filters become the dominant filtration method in most countries in all over the world. Sand classification may be accomplished in the rapid backwashing of filters by leaving fine sand on the top which consequently can limit the capacity of the traditional rapid sand filters. Floc particles that have been removed in filtration process may be accumulated on the upper layers of the filter causing 
most non-nexploited filter thickness (Al-Rawi, 2009). Charcoal shows better performance than gravel when it used as a filter for removing or decreasing turbidity, because charcoal may have a slightly higher surface and porous than gravel which in turn can increase sedimentation and other corresponding filtration processes such as adsorption (Nkwonta et al., 2010). Single plastic filters and dual filters produce water of the same high quality as sand filter. Plastic filters were slower in developing head losses by $<8-78 \%$ and had a longer running time than the sand filter while dual filters were slower in developing head losses by about $14-16 \%$ and had a run time of about $12-40 \%$ of the sand filter (Al-Baidhani and Shubir, 2013). Using the anthracite material as a layer of the dual-media filter enhances the removal efficiency of organic matter compared with a filter using single media (Noredinvand et al., 2016).

This study aims to exploit the waste of constructive materials in water filtration. The selected material in this study is the waste of granite used as a constructive material for floor coverings.

(a)

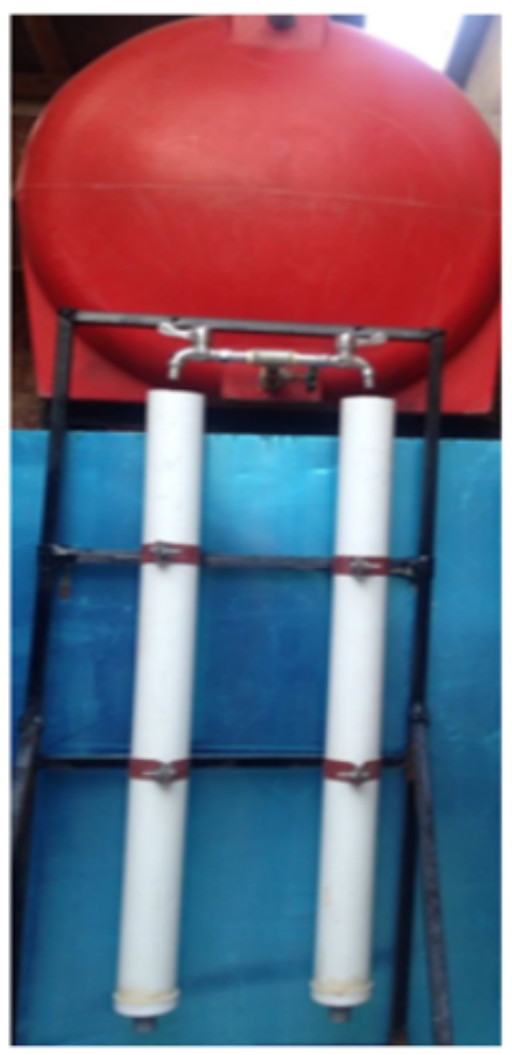

(b)

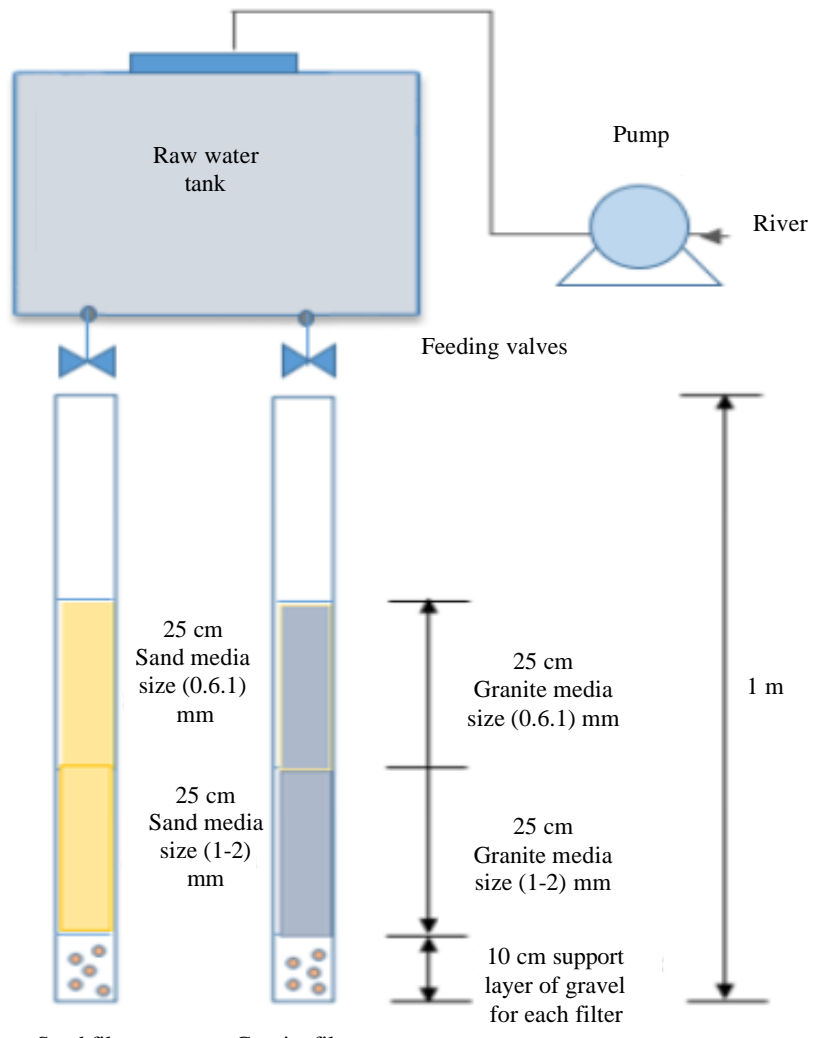

Fig. 1: a) Pilot plant and b) Schematic diagram of pilot plant 
(a)

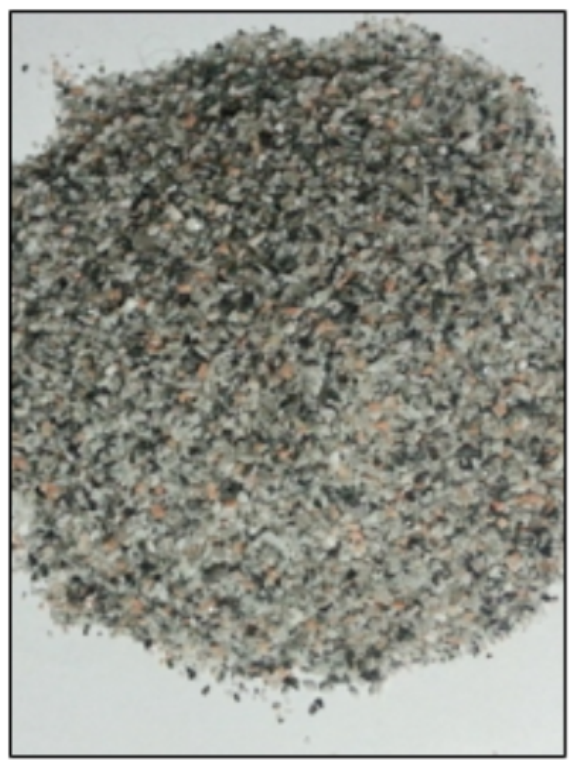

(b)

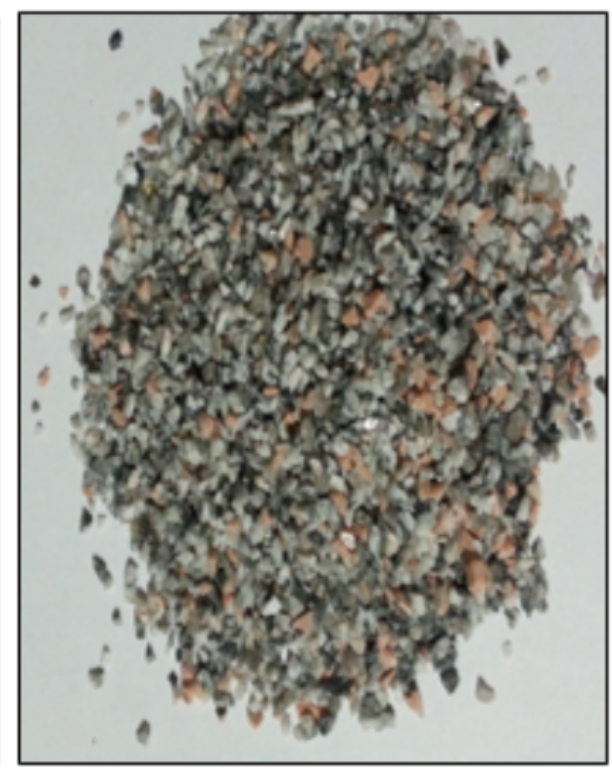

Fig. 2: The grain sizes of waste granite media filter: a) $0.6-1 \mathrm{~mm}$ and b) 1-2 mm

\section{RESULTS AND DISCUSSION}

Figure 3 shows the turbidity removal efficiency of sand and granite filters at the first run which was carried out with filtration rate of $5 \mathrm{~m} / \mathrm{h}, \mathrm{pH}$ of 7.6 , total dissolved solids TDS of $595 \mathrm{ppm}$, Temperature (T) of $30^{\circ} \mathrm{C}$ and Electrical conductivity Ec of $1193 \mu \mathrm{S} / \mathrm{cm}$. The maximum values of turbidity removal efficiency at first run were 84.89 and 84.12 for sand and granite filters, respectively.

Figure 4 shows the turbidity removal efficiency of sand filter and the granite filter at second run which was carried out with filtration rate of $7.5 \mathrm{~m} / \mathrm{h}, \mathrm{pH}$ of 7.8 , TDS of $621 \mathrm{ppm}, \mathrm{Ec}$ of $1237 \mu \mathrm{S} / \mathrm{cm}$ and $\mathrm{T}$ of $31^{\circ} \mathrm{C}$. The maximum values of turbidity removal efficiency at second run were 80.66 and 74.77 for sand and granite filters, respectively. Figure 5 shows the removal efficiency of Total Suspended Solid (TSS) of sand filter and the granite filters at first run. The maximum values of removal efficiency of Total Suspended Solid (TSS) at first run were 84.77 and 82.44 for sand and granite filters, respectively.

Figure 6 shows the removal efficiency of Total Suspended Solid (TSS) of the sand filter and the granite filters at second run. The max values of removal efficiency of Total Suspended Solid (TSS) at second run were 80.55 and 76.68 for sand and granite filters, respectively. The removal efficiency of filter depend on many factors such as filtration velocity, running time, grain size of filter media, thikness of filter media and water

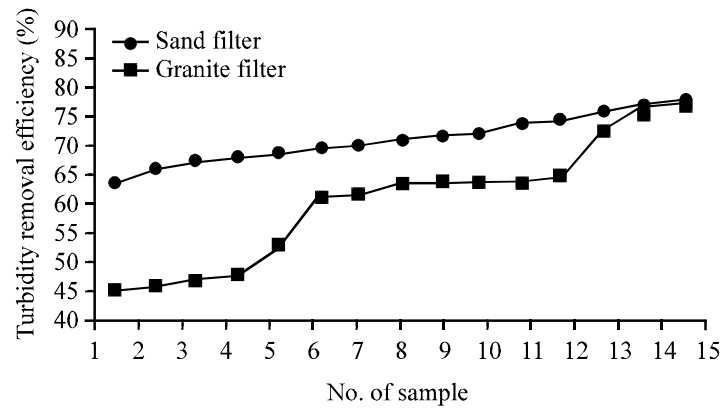

Fig. 3: Comparison between the turbidity removal efficiency of the sand filter and that of the granite filter at the first run (filtration rate $=5 \mathrm{~m} / \mathrm{h}, \mathrm{pH}=$ 7.6, $\mathrm{TDS}=595 \mathrm{ppm}, \mathrm{Ec} .=1193 \mu \mathrm{S} / \mathrm{cm}, \mathrm{T}=30^{\circ} \mathrm{C}$ )

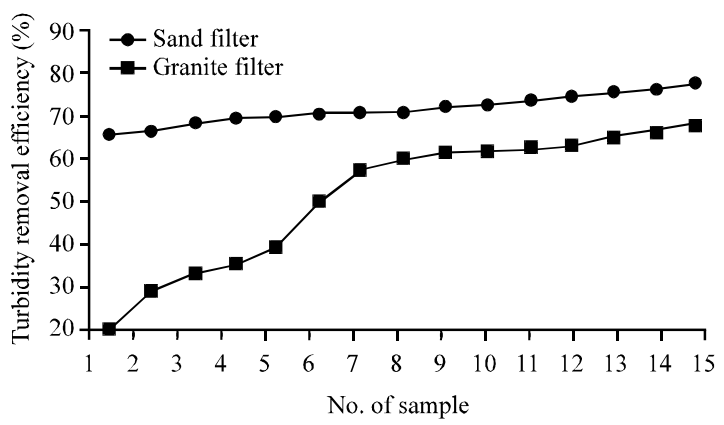

Fig. 4: Comparison of the turbidity removal efficiency between the sand filter and the granite filter at second run (filtration rate $=7.5 \mathrm{~m} / \mathrm{h}, \mathrm{pH}=7.8$, $\mathrm{TDS}=621 \mathrm{ppm}, \mathrm{Ec}=1237 \mu \mathrm{S} / \mathrm{cm}, \mathrm{T}=31^{\circ} \mathrm{C}$ ) 


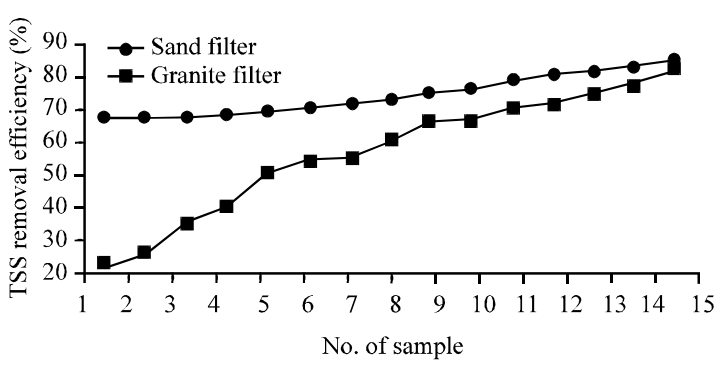

Fig. 5: Comparison of the removal efficiency of Total Suspended Solid (TSS) between the sand filter and the granite filter at first run (Filtration rate $=5$ $\mathrm{m} / \mathrm{h}, \mathrm{pH}=7.6, \mathrm{TDS}=595 \mathrm{ppm}, \mathrm{Ec}=1193 \mu \mathrm{S} / \mathrm{cm}, \mathrm{T}$ $=30^{\circ} \mathrm{C}$ )

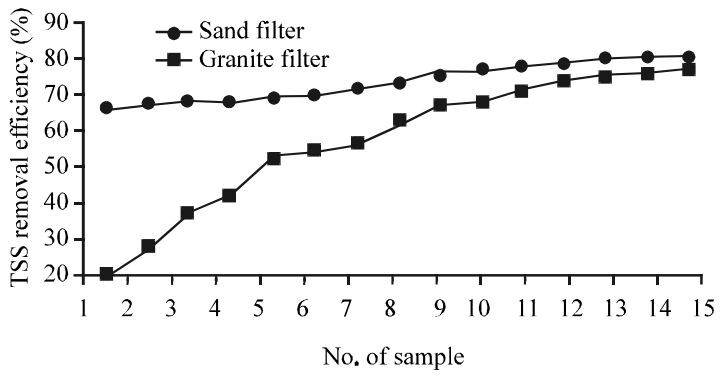

Fig. 6: Comparison of the removal efficiency of Total Suspended Solid (TSS) between the sand filter and the granite filter at second run (Filtration rate $=7.5 \mathrm{~m} / \mathrm{h}, \mathrm{pH}=7.8, \mathrm{TDS}=621 \mathrm{ppm}$, Ec. $=$ $1237 \mu \mathrm{S} / \mathrm{cm}, \mathrm{T}=31^{\circ} \mathrm{C}$ )

properties, especially turbidity and total suspended solids (Binnie et al., 2002). The results demonstrated that the removal efficiency of turbidity and total suspended solid of sand and granite filters increase with the increase of the running time. In addition, the experimental results carried out at both runs reveal that the removal efficiency of turbidity and TSS of granite filter approach the removal efficiency of sand filter, thus, it can be deduced that the granite filter gives convincing results as a filter media.

\section{CONCLUSION}

The experimental results of this research covering both runs reveal that the removal efficiency of turbidity and TSS of granite filter can be competitive to the removal efficiency of sand filter. It can be concluded that the granite filter gives satisfactory results as filter media. This in turn adds that the wastes of some construction materials namely granite can be considered worthily in the exploitation of designing reliable water filters.

\section{REFERENCES}

Al-Baidhani, J.H.A. and M.D. Shubir, 2013. A New attempt of using crushed plastic solid wastes in water filtration. J. Civil Eng. Archit., 7: 227-237.

Al-Rawi, S.M., 2009. Introducing sand filter capping for turbidity removal for potable water treatment plants of Mosul/Iraq. Intl. J. Water Resour. Environ. Eng., 1: 011-019.

Binnnie, C., M. Kimber and G. Smethrust, 2002. Basic Water Treatment. 3rd Edn., Royal Society of Chemistry, Cambridge, UK., ISBN-13: 978-0854049899, Pages: 292.

Bourke, N., G. Carty, M. Crowe and M. Lambert, 1995. Water Treatment Manuals: Filtration. Environmental Protection Agency, Ireland, Pages: 76.

Gholikandi, G.B., E. Dehghanifard, M.N. Sepehr, A. Torabian and S. Moalej et al., 2012. Performance evaluation of different filter media in turbidity removal from water by application of modified qualitative indices. Iran. J. Publ. Health, 41: 87-93.

Kiagho, B., R. Machunda, A. Hilonga and K. Njau, 2016. Performance of water filters towards the removal of selected pollutants in Arusha, Tanzania. Tanzania J. Sci., 42: 136-149.

Nkwonta, O.I., O.A. Olufayo, G.M. Ochieng, J.A. Adeyemo and F.A. Otieno, 2010. Turbidity removal: Gravel and charcoal as roughing filtration media. South Afr. J. Sci., 106: 1-5.

Noredinvand, K.B., A. Takdastan and J.R. Yengejeh, 2016. Removal of organic matter from drinking water by single and dual media filtration: A comparative pilot study. Desalin. Water Treat., 57: 20792-20799.

Zouboulis, A., G. Traskas and P. Samaras, 2007. Comparison of single and dual media filtration in a full-scale drinking water treatment plant. Desalination, 213: 334-342. 